Szymon Biliński, Bartosz Drzewiecki

\title{
Tekst utworu punkowego jako komentarz do wydarzeń politycznych lat 80-tych i 90-tych w Polsce
}

Chociaż kultura punkowa istnieje już od ponad 25 lat, w społeczeństwie ciągle funkcjonuje pewien stereotyp złego, nieokrzesanego i agresywnego punka, a fryzura "na irokeza" cały czas wywoluje dziwne reakcje. Nieliczni znają subkulturę punk i niewielu wie, czym ona naprawdę jest. Powód takiego stanu rzeczy należałoby thumaczyć niechęcią i strachem badaczy, przez co badania dotyczące tej subkultury są nadal ubogie.

Do nielicznych należą prace gruntownie przedstawiające tę problematykę, publikacje te zazwyczaj ograniczają się do krótkich artykułów. Historię podkultury punk $w$ rzeczywistości angielskiej zbadał $B$. Kurowski ${ }^{1}$, zaś najbardziej zasłużonymi badaczami tej kultury młodzieżowej w Polsce, zwłaszcza tematu festiwalu jarocińskiego, są J. Wertenstein-Żuławski i M. Pęczak². Tekstami rockowymi oraz nazwami grup muzycznych zajmowali się - z punktu widzenia językoznawstwa - H. Zgółkowa i K. Szymoniak ${ }^{3}$. Badania poruszanego przez nas zagadnienia nie byłyby możliwe, gdyby nie publikacje dziennikarzy muzycznych, zwłaszcza M. Lizuta $^{4}$, M. Czubaja ${ }^{5}$ i J. A. Rzewuskiego ${ }^{6}$ i R. Sankowskiego ${ }^{7}$. Ważnym wydarzeniem

\footnotetext{
'B. Kurowski, Punk - pokolenie pustki, Kraków 1997.
}

${ }^{2}$ Spontaniczna kultura młodzieżowa - wybrane zjawiska, pod red. J. Wertenstein-Żuławskiego i M. Pęczaka, Wrocław 1991; M. Pęczak, Maly stownik subkultur mtodzieżowych, Warszawa 1992; idem, Kto wywiesi biald flagę, Więż, 1983, nr 6, s. 41-52; idem, Ostra psychoska, Polityka, 2003, nr 10, s. 58-60; J. Wertenstein-Zuławski, No future?, Więż, 1987, nr 6, s. 21-28; idem, To tylko rock'n'roll, Warszawa 1999; Wybrane zagadnienia spontanicznej kultury miodzieżowej w Polsce, pod red. Z. Rykowskiego, J. Wertenstein-Zuławskiego, Warszawa 1985.

${ }^{3}$ H. Zgółkowa, K. Szymoniak, „Stowa chore od stów”, czyli polscy rockmani o języku, [w:] Jezyk zwierciadlem kultury, czyli nasza codzienna polszczyzna, red. H. Zgólkowa, Poznań 1988, s. 84-97; iidem, Prowokacja, czyli o nazwach polskich zespotów rockowych, [w:] Język zwierciadlem..., s. $98-109$.

${ }^{4}$ M. Lizut, Pogo w Bieszczadach, Gazeta Wyborcza, 2003, nr 101, s. 17-18; idem, Gramy gdy pojawiajq sig duchy [rozmowa $z$ Tomaszem Lipinskim $i$ Robertem Brylewskim], Gazeta Wyborcza, 2003, nr 138, s. 16 17 .

${ }^{5} \mathrm{M}$. Czubaj, Kwiaty na śmietniku: czy punk rock byl wielkim oszustwem?, Polityka, 2000, nr 49, s. 64-68; idem, Polityku nie ściemniaj. Śpiewana historia III RP, Polityka, 2001, nr 48, s. 51-52. 
było opublikowanie w roku 2003 zbioru wywiadów z gwiazdami polskiego punka, przedstawiających ich spojrzenie na subkulturę $z$ perspektywy lat ${ }^{8}$.

Punk, jako subkultura i muzyka, powstał w połowie lat siedemdziesiątych. Nie wiadomo, czy w USA, czy Wielkiej Brytanii. Idealnie nasowal do rzeczywistości - szczególnie angielskiej - tych czasów. Stał się swoistą odpowiedzią i komentarzem do sytuacji społecznej i politycznej, nie proponując jednak pomysłów na zmiany, nie tworząc żadnych alternatywnych rozwiązań. Punk kwestionuje wszystko i wszystkich, porządek i nieporządek, a głównie kapitalistyczny model produkcji i konsumpcji ${ }^{9}$. Kontestacja objawiała się, między innymi, przyjęciem za swój wyróżnik ubóstwa. Negacja życia spolecznego, a nawet kultury jako szansy uspołecznienia jego twórców, sprawiły, że w nowej subkulturze widziano wroga. Sprawę uznano za tak poważną, że zajmował się nią nawet brytyjski parlament, uznając punk rock za zagrożenia porządku publicznego ${ }^{10}$.

Bunt punka jako muzyki objawiał się przede wszystkim w jego prymitywizmie, również $w$ warstwie tekstowej. Instrumentalna prostota, niedbałość o warsztat, była swoistym protestem przeciwko panującej w latach 70-tych rockowej i dyskotekowej komercji. Demonstrację niezależności od przemysłu rozrywkowego stanowiło również nagrywanie $w$ amatorskich, ubogich studiach w adaptowanych na ten cel przypadkowych pomieszczeniach ${ }^{11}$. Styl muzyki punk wiązał się zapewne również $\mathrm{z}$ jego otwartością na młodych, niewiele jeszcze umiejących twórców - amatorów ${ }^{12}$. Każdy mógł przecież wziąć do ręki gitarę i wykrzyczeć, co mu leży na sercu.

Tekst piosenki punkowej posiada swoją własną specyfikę i charakterystykę. Układa go zazwyczaj sam wykonawca lub członek zespołu, nie istnieje tutaj „profesja" zawodowego tekściarza, występująca w innych gatunkach muzyki, np. pop. Tekst zazwyczaj jest prosty, składający się $z$ kilku słów lub rozwinięty do paru krótkich zwrotek, przy czym zazwyczaj piosenka trwa około dwóch minut. Mimo to w punku trudno znaleźć teksty traktujące o niczym. Piosenka to zawsze okazja do wyrażenia swoich poglądów i komentarzy na dany temat. Poprzez słowo staje się źródłem informacji i komunikacji z całą grupą, niezależnie od tego, czy zespół cieszy się popularnością tylko na własnym osiedlu, czy w całym kraju. Punk daje szansę pokazania siebie, artykulacji jemu tylko właściwych ideałów oraz wątpliwości targających życiem młodego człowieka.

Głównym, a czasami jedynym orężem zespołów punkowych jest prowokacja. Stała się ona wręcz cechą gatunku muzycznego - wielu stosuje ją nie tyle ze

${ }^{6}$ J. A. Rzewuski, Dziesięć lat później, Magazyn muzyczny - Jazz, nr 2, 1986, s. 11-13; iđ̆en, The Clash - dzieci z brudnej ulicy, Tylko Rock, 1993, nr 11, s. 30-36.

'R. Sankowski, Sex Pistols. Aniotowie o brudnych twarzach, Tylko Rock, 1994, nr 12, s. 40-45.

${ }^{8}$ M. Lizut, Punk Rock Later, Warszawa 2003.

${ }^{9}$ W. Siwak, Estetyka rocka, Warszawa 1993, s. 48.

1" G. Castello, Ziemia obiecana - kultura rocka 1954-1994, Kraków 1997, s. 234-237.

"M. Pęczak, Maly slownik..., s. 71.

${ }^{12}$ L. Janik, Rock jako przedmiot zainteresowania mtodziezy, Kultura i Społeczeństwo, t. XXVII, nr 2, s. 129. 
względów ideowych, co dla samej siebie. Wówczas użycie wulgaryzmów i bulwersujących opinii nie wnosi niczego nowego do podkultury punk. Większość jednak prowokuje, aby pomóc odbiorcy "otworzyć oczy", by uwrażliwić przypadkowego nieraz widza, zmusić do zastanowienia się nad czymś, czego zwykle nie dostrzega lub po prostu bagatelizuje, po to, by wprawić go czasem w zakłopotanie.

Specyficzny, ale i bardzo ważny rodzaj prowokacji stanowi sama nazwa zespołu. Często już ona jest sugestywnym wyróżnikiem grupy punkowej od „niepunkowej” ${ }^{13}$. Dzięki niej grupa prowokuje już przy pierwszym zetknięciu, jeszcze przed przedstawieniem swoich poglądów za pomocą tekstów. Nazwy takie jak „Dezerter" czy „Kryzys” doskonale komentują realia PRL-น.

Na przelomie lat 70-tych i 80-tych pojawiła się nadzieja na demokratyczne przemiany w naszej części Europy. Polska mlodzież dopiero poznawała muzykę punkową zza zachodniej granicy, a wiadomym jest, że było to bardzo utrudnione. Wszelkie dostępne w Polsce media były kontrolowane i zmonopolizowane przez polską muzykę rozrywkową. Jednak sporadycznie nadawane utwory zarówno przez Radio Wolna Europa jak i Radio Luksemburg, a także nieliczne płyty i nagrania przywożone $z$ krajów, gdzie muzyka punkowa już istniała, wystarczyły, aby ta subkultura zaistniała także na polskim gruncie.

Warunki dla jej zakiełkowania i rozwoju były sprzyjające. W kraju nastąpił czas „rozchwiania systemu wartości i pogorszenia [...] perspektyw ekonomicznych i politycznych"14. Kryzys władzy państwowej i ożywienie się działaczy opozycyjnych w roku osiemdziesiątym, stwarzał destabilizacyjną lukę, w której mógł się ten ruch rozwijać. Przy czym punki widziały w nowej sile, jaką była „Solidarność, przyszłą klasę rządzącą, a więc i wroga, nowy system, którego, zgodnie ze swoimi ideałami, żadną miarą nie mogli poprzeć. Oczywiste wydawać by się mogło, że polski punk był antykomunistyczny, a zachodni antykapitalistyczny. Stwierdzenie to byłoby jednak dużym uproszczeniem - muzycy ci byli przecież apolityczni ${ }^{15}$. Jak mówi Krzysztof Grabowski z zespołu „Dezerter”: „[...] zawsze jest jakiś system, który można kontestować. Upada jeden, a w jego miejsce pojawia się następny"16. Twórcy muzyki punkowej stali się nieusuwalnym tworem, komentującym na bieżąco polską rzeczywistość. Kierowali się zasadą, że niezależnie od tego, jaki jest system rządów, jest to zawsze system, który ogranicza i któremu należy się przeciwstawiać. Naleźy być odrębnym i bezkompromisowym, stawiać na swoim i nie zważać na to, co mówią inni:

Nie jestem duży, nie jestem maly,

Nie jestem mądry, nie jestem glupi,

${ }^{13}$ Np. Dead Kennedys, czy poiskie: Schizofreniczna Prostytutka Maria, Smierć Kliniczna, Sedes, Scierwo, Ściek, Patologia Ciąży.

${ }^{14}$ M. Kielak-Adamowicz, Polski punk, [w:] Spontaniczna kultura..., s. 238.

${ }^{15} \mathrm{M}$. Filipiak, Od subkultury do kultury alternatywnej - wprowadzenie do subkultur mlodzieżowych, Lublin 1999, s. 70.

${ }^{16}$ Cyt. za: M. Lizut, Punk Rock Later.., s. 116. 
Nie jestem $w$ ZMS-ie, nie jestem $w$ KOR-ze,

Nie jestem $w$ partii, nie jestem kurwa niczym ${ }^{17}$.

Punk jako jedyny dawał młodym ludziom możliwość na nieskrępowane niczym wykrzyczenie swoich myśli. Wystarczyło niewiele - próby odbywały się w garażach, wolno stojących domach, gdziekolwiek, byleby można pośpiewać.

Śpiewano o sprawach ważnych dla kraju, jak i o zwykłych, „szarych” obywatelach. Bez przerwy przypominano władzom i cenzorom, że polska młodzież istnieje i nie podoba jej się aktualny stan rzeczy. Komentowano rzeczywistość polityczną i kulturalną, wydarzenia na świecie oraz rozprawiano się $z$ radzieckimi towarzyszami.

Muzycy punk chętnie wyrażali opinie o bolesnej - związanej z rządami Stalina - przeszłości, a także związkach $z$ ówczesną władzą radziecką. Był to rodzaj swoistego odreagowania spraw teraźniejszych i próba rozliczenia się z nieustępliwym sąsiadem. ZSRR tworzył system, był wrogiem, widocznym, często wyśmiewanym i nienawidzonym, bezpieczniej jednak bylo zająć się przeszlością, krytykowaną przecież również przez rządzących współcześnie:

Hej dziewczyno, hej niebogo jakieś wojsko idzie droga!

Schowaj pieniagdze, schowaj zegarek! Kryj się, kryj! [...]

A ten gruby, co na przedzie, na kradzionym koniu jedzie,

To Rokossowski, marszatek polski! Kryj się, kryj! [...]

A ja myślałem, że to Oni, że to banda bandę goni,

A to Czerwoni, Czerwoni! Kryj sie, kryj!!

Dostawało się jednak wszystkim. Toruńska "Rejestracja” w swoich tekstach dała wyraz dezaprobaty również dla polityki wybranego 4 grudnia 1980 roku prezydenta Stanów Zjednoczonych Ronalda Reagana, dezaprobaty dla polityki zaostrzenia konfliktu, wymagającej nowych zbrojen.

Jedzie kowboj jedzie bombę ma przy siodle,

Jak się zdenerwuje to pewnie jq̨ rąbnie.

Mity nasz kowboju lepiej jej nie rzucaj,

Bo jak trafisz obok to będzie poruta.

Reagan, Reagan, Reagan dziki zachód,

Gwiezdne wojny pośla nas do piachu ${ }^{19}$.

Także wybuch stanu wojennego wywołał szeroki oddźwięk w środowisku muzycznym, szczególnie punkowym. Już przed tym wydarzeniem wojna i przemoc były częstym tematem utworów, nic dziwnego więc, że w 1982 roku każdy chciał

\footnotetext{
${ }^{17}$ Walek Dzedzej Pank Bend - Nie jestem (1979).

${ }^{18}$ Poland - Sowieci (1980); zob. też: Rejestracja - Wokót nas (uklad) (1981).

${ }^{19}$ Cmentarna elita - Walczyk (1983).
} 
się wypowiedzieć na ten temat. Opinie padały z różnych ust, jednak zawsze wyrażały dezaprobatę dla działań polityków - wojskowych.

Wojna- maszeruja niewolnicy,

Wojna - będą na was polować,

Wojna-będa was zabijać,

Wojna - będą eksterminowac ${ }^{20}$.

W trakcie stanu wojennego okazało się, jak ważnym i potrzebnym wydarzeniem w polskim świecie muzycznym był istniejący od roku 1980 festiwal w Jarocinie. Nie przestał on trwać mimo represji, jakie spadły na opozycję. Cenzura festiwalowa stawiała przed wykonawcami trudne zadanie jej ominięcia, wspomina się też o ZOMO czekającym w lesie na interwencję ${ }^{21}$.

Po zakończeniu stanu wojennego spoleczeństwo polskie, zdezorientowane ostatnimi wydarzeniami, nie miało sily na walkę. Młodzi muzycy pozostawali jedną z nielicznych ostoi buntu, a okres ten niewątpliwie sprzyjał takiej postawie ${ }^{22}$.

Pokolenie matp prowadzi nas (...)

Prawda w oczy kole

To nie ludzie - to gnoje ${ }^{23}$.

Negowano więc na przyklad wszelkie przejawy aktywności społecznej narzucone przez państwo, np. Swięto Pracy:

To jest święty dzień majowego święta,

Wielki pochód oszukanych thumów,

Zniewoleni lękiem przed sankcjami,

Niosq hasla, w które nie wierzą.

Dumna armia kroczy za nimi,

Demonstrując swoją bron i swoja silę?

Wyrażano swój negatywny stosunek do polityków, zarówno tych rządzących, opozycji solidarnościowej, jak i polityków już nieaktywnych. Zespół „Patologia ciąży" śpiewał:

Trzeba nakraść jeszcze więcej,

trzeba węgla trzeba stali,

${ }^{20}$ Brygada Kryzys - Wojna (1982)

${ }^{21}$ J. Wertenstein-Żuławski, Karnawal szarych ludzi: Jarocin 1980-1986, [w:] Spontaniczna kultura..., s. 221; patrz też: K. Lesiakowski, P. Perzyna, T. Toborek, Jarocin w obiektywie bezpieki, Warszawa 2004.

${ }^{22}$ M. Szymańczak, Czy subkultury sq autentyczne?, Okolice, 1987, nr 3, s. 34.

${ }^{23}$ Moskwa - Pokolenie matp (1984).

${ }^{24}$ Kaftan bezpieczeństwa - Pochód (1985). 
gdy o litość wotal Edek,

wtedy mu nie darowali ${ }^{25}$.

W rządzących upatrywano winnych niedogodności codziennego życia.

Teksty punkowe zachęcały też do przebudzenia się narodu polskiego i obalenia komunizmu. Upadek systemu był ziszczeniem się marzeń o wolnej Polsce i życiu dającym nadzieję na lepsze jutro:

Proletariackie madonny,

Petne herezji i grzechu.

Niezmienne rytmy szychty,

Buldozery o przyspieszonym oddechu.

Doskonata maszyna,

Zaczyna się zacinać ${ }^{26}$.

Po roku 1989 szybko zauważono jednak, że nowy ustrój jest w wielu miejscach podobny do starego. Dla zwykłego obywatela zmieniło się niewiele. $Z$ dnia na dzień uzyskał on wiele swobód obywatelskich, jednak w jego domu nadal gościła bieda. Nic dziwnego więc, że muzycy punk - z założenia nastawieni sceptycznie do każdego systemu - także widzieli i nadal widzą zmianę ustroju w czarnych kolorach ${ }^{27}$. Dla nich oczywiście zmieniło się trochę więcej: „[...] był to dziwny czas bo stałem się gwiazdą rocka" ${ }^{32}$, wspomina Budzyński. Zmiana ustroju nie mogła zmienić wiele w postawach punkowych:

Postawiq sobie pomnik bohatera,

Wybiora sobie nowego premiera,

Stworzq nowy system polityczny,

I bẹdq dumni, że jest demokratyczny.

Znowu szwindel szykuja nowy.

Znów chca się dobrac do twojej giowy ${ }^{29}$.

Jednak ze wszystkim, co kojarzyło się z poprzednim ustrojem, żegnano się bardzo chętnie $e^{30}$. Nieraz sentymentalnie, lecz tendencją bylo radykalne odcinanie się od przeszłości. Ustrój socjalistyczny był znany i wiadomo było, czego po nim można się spodziewać - represji, ataków i braku perspektyw - większość miała już tego dosyć i nie chciała do niego wracać. Demokracja była ustrojem nowym i nieznanym. Najwięcej wiedziały o nim osoby, które bezpośrednio o niego wal-

${ }^{25}$ Patologia ciąży - Emeryci (1984).

${ }^{26}$ Pidżama Porno - Codzienność (1987).

${ }^{27}$ Zob.: Blade Loki - System (1993); Apatia - Państwo (1997).

${ }^{28}$ M. Lizut, Punk Rock Later..., s. 79; patrz też: M. Lizut, Taki byl duch czasu [wywiad $z$ Tomaszem Budzyńskim], Gazeta Wyborcza, 2003, nr 56, s. 20-21.

${ }^{29}$ Dezerter - Szwindel (1987).

${ }^{30}$ Zob.: Big Cyc - Piosenka góralska (1980); Kult - Stara ich armada (1988). 
czyly, co stwarzało pewność, że to one będą tworzyly nowe elity władzy. Nie trzeba było więc długo szukać ofiar ataków kolejnych fal ruchu punkowego. Nienawiść do PZPR po pewnym czasie przeniosła się na nowopowstałe partie demokratyczne, gdyż okazało się, że dla wielu bycie u władzy stanowiło więksszą wartość niż zmienianie rzeczywistości.

Zmiana ustrojowa wymusiła pewną rewolucję na muzycznej scenie punkowej. Wytworzył się na niej pewien podział. Poszczególne zespoły zazwyczaj nie istniaty długo. Najczęściej był to okres pięcioletni, przypadający na największy okres młodzieńczego buntu wśród nastolatków. Do rzadkości należały zespoły, które grają dłuźej niż dziesięć lat, bez jakiejkolwiek zmiany w stylistyce i kompozycji tekstowej. Scena podzieliła się wzdłuż linii wieku. Nadal grały i funkcjonowały zespoły z początku lat osiemdziesiątych, jednak ich muzyka ulegała pewnym złagodzeniom. Pojawiły się też nowe, powstałe $w$ demokracji kapele, które nie znały problemów, o jakich śpiewali ich starsi koledzy. Wyrosłe w rudymentarnej fazie rozwoju punka w Polsce grupy $z$ trudem radziły sobie z nowymi realiami po 1989 roku $^{31} . \mathrm{Z}$ tej swoistej walki zwycięsko wyszło niewielu. Można więc mówić o starej i nowej szkole polskiego punka. W latach dziewięćdziesiątych okazało się, że wszyscy muzycy działają na jednym rynku, gdzie należy dbać o swojego odbiorcę, niemal o niego walczyć. Punk jednak, początek lat dziewięćdziesiątych, przetrwał $w$ dobrej formie. Szybko okazało się, że jest o czym i do kogo śpiewaćc $c^{32}$. Kolejne pokolenia młodzieży wyrażały swą dezaprobatę dla rządzących i przemian spolecznych lub ich braku ${ }^{33}$.

Do tematyki politycznej nawiązywał wtedy w swoich utworach zespół „Big Cyc". Ich pierwsza płyta wydana w 1990 roku pt. "Z partyjnym pozdrowieniem" zawierała szereg piosenek poruszających problematykę zmiany ustroju i przemian w świadomości ludzkiej. Brak cenzury, która była instytucją najbardziej walczącą o czystość przekazu medialnego w PRL, pozwolił zespołowi zamieścić na okładce płyty wizerunek Lenina $z$ irokezem. W sferze obyczajowej zmieniło się więc wiele.

Radość, jaką wzbudziło wybranie pierwszego demokratycznego prezydenta, szybko się skończyła, a punkowe hasło „nie wierzę politykom" zaktualizowano do "nie wierzę elektrykom”. Autorem tej parafrazy był właśnie zespół „Big Cyc”, który szczególnie upodobał sobie postać Wałęsy. Wizerunek tego ostatniego został umieszczony na okładce drugiej płyty. zespołu, stanowiąc pewną całość z okładką pierwszej.

Polityka i wybory nadal pozostawały jednym z wiodących tematów utworów na przestrzeni lat 1991-2000. Demokracja wprowadziła wolność słowa i wypowiedzi, więc muzycy coraz częściej wypowiadali się wprost przeciwko konkretnym ludziom i instytucjom państwa ${ }^{34}$. Lata osiemdziesiąte nauczyly ludzi niewiary w zapewnienia władz o poprawie sytuacji $w$ kraju. Sceptycyzm do tego typu obietnic, który wyznawali również muzycy punk, przekazany został ich widowni. Na-

\footnotetext{
"M. Lizut, Grany..., s. 16.

${ }^{32}$ Por: Włochaty - Rebelia (1991).

${ }^{33}$ Zob.: Kult - Wódka (1982); por:: Ga Ga - Monopole (alkohole) (1995).

${ }^{34}$ Zob.: Ga Ga - Rząd jest zajęty swoimi sprawami (1993); M. Caubaj, Polityłu nie ściemriaj..., s. 52.
} 
mawiano ją, aby nie wierzyła w hasła wyborcze preparowane dla zdobycia większego elektoratu:

I poszedleś w petni wiary na wybory

I skreslities to czego uczyli cię przez caly czas

I cieszyteśsię że pomogleśs swej ojczyźnie,

Która bardzo wdzięczna jest $z$ a to tobie.

A ja wiem i tak w Polsce będzie zle,e,

A ja wiem od czterdziestu lat nic nie zmienito sie?

Glosuj na mnie - wtedy dostaniesz, prawie za darmo każde śniadanie.

Człowiek na odpowiednim miejscu, powiedzie ciebie ku szczęściu.

Tak dalej być nie musi, zamknáć granice przed braćmi z Rusi.

A niech bogacze oddadza patace, milion nowych miejsc pracy. [...]

Piwo $i$ wóda dostępne już w sklepie, urzędnik jednak wie lepiej ${ }^{36}$,

gdzie "Człowiek na odpowiednim miejscu” to hasło wyborcze Tadeusza Mazowieckiego $\mathrm{z}$ wyborów na prezydenta $\mathrm{z} 1990$ roku, "Tak dalej być nie musi” hasło SLD z wyborów parlamentarnych z 1993 roku, "Milion nowych miejsc pracy" to hasło Kongresu Liberalno-Demokratycznego $\mathrm{z}$ tych samych wyborów, a słowa "Urzędnik jednak wie lepiej” to parafraza hasła "Solidarności”, również z wyborów z 1993 r., które brzmiało: „Wyborca jednak wie lepiej”.

Symboliczny wymiar miało wycofanie się ostatnich jednostek armii rosyjskiej $z$ terenów Rzeczypospolitej. Ich pobyt w naszym kraju skomentowal zespół „Piersi” w utworze „Marsz KPN” z 1992 roku. Zespół śpiewal: „Mają w Brzegu i w Legnicy auta, czołgi bolszewicy, a ja nie chcę by mnie strzegl komunistyczny młot i sierp".

Podczas nieudolnych rządów prawicy powróciły resentymenty za starym ustrojem. Wyrazem tego było zwycięstwo SLD w wyborach parlamentarnych w 1993 roku oraz wybór Aleksandra Kwaśniewskiego na prezydenta w 1995.

Muzycy punkowi postawy takie wyszydzali. Pamięć porządku przed 1989 roku nie pozwalała na jego gloryfikowanie. Na ławach SLD zasiadali ludzie współtworzący dawną „elitę polityczną”, dlatego też punkowcy z ochotą rozwijali skrót PZPR do Sojusz Lewicy Demokratycznej.

Zielonogótska "Jugosławia" przestrzegała przed postawami prolewicowymi ${ }^{37}$ i powtórzeniem się rządów typu peerelowskiego. Zauważyli, że ówczesna lewa strona polityczna przypominała klasę rządzącą sprzed kilku lat:

Starzy klamcy lecz nowe schematy,

To przez nich, zamiast ludzi same emblematy.

${ }^{35}$ Cela nr 3-Naiwniak (1997).

${ }^{36}$ Kult - Keszitsen kepet onmagarol (1994).

${ }^{37}$ Zob. też: Big Cyc-Strzeż się tych palantów (1995). 
Znów wymyśla nowe bzdury, klamstwa,

To ta sama komunistyczna armia ${ }^{38}$.

Inni próbowali zniechęcić poprzez wyśmianie rzeczywistości lat osiemdziesiątych zdaniami typu: „I jak fajnie żreć salceson, jeździć tylko trabantami” ${ }^{39}$, czy: „Niech wróci komuna i tania kiełbasa, pół litra na głowę i piwo na kaca”40.

Następne lata pokazały, że miejsca w kolejnych sondażach nie mają większego znaczenia i praktycznie każdy polityk rozczarowywał ${ }^{41}$. Prasa donosiła także o powiązaniach świata polityki ze światem przestępczym. Dla niektórych muzyków jasne stało się, że zorganizowane grupy przestępcze, bez cichego wsparcia władzy - choćby na najniższym szczeblu - nie rozwijałyby się tak łatwo. Mafia potrzebna była rządzącym, tak jak i rządzący mafii:

Potrzebny nam czlowiek u samego szczytu władzy,

Będziesz politykiem by zalatwiać nasze sprawy.

Ty jesteś chtopak z naszej dzielnicy,

Przeżyteś lata strachu i prohibicji.

I takie jest wiaśnie życie, życie to nie bajka,

Chcesz być politykiem, do tego potrzebna ci mafia ${ }^{42}$.

Polityczna poprawnośćc ${ }^{43}$ na przestrzeni dekady nie byla mocną stroną, zarówno rządzących, jak i opozycjonistów. Państwo jawiło się raczej jako kontroler, poborca podatkowy oraz beneficjent dochodów z pracy swoich obywateli, ledwo wiążących koniec $z$ końcem, a także jako twórca praw, ograniczających swobody obywatelskie i wprowadzających bałagan:

Zapisany w statystykach, mam swój numer i nazwisko,

Adres miejsca wegetacji - oni wiedzq o mnie wszystko.

Znają datę urodzenia, datę śmierci przybliżona,

Wiedzq czy się masturbuję, jakq̨ szkolę mam skończon $q^{44}$.

To nasza demokracja, przepych i dobrobyt,

Kolejne reformy uzdrawiaja kraj,

Od tego wszystkiego po prostu nas zatkalo,

Nie wiemy, co do czego, nie wiemy, co i jak ${ }^{45}$.

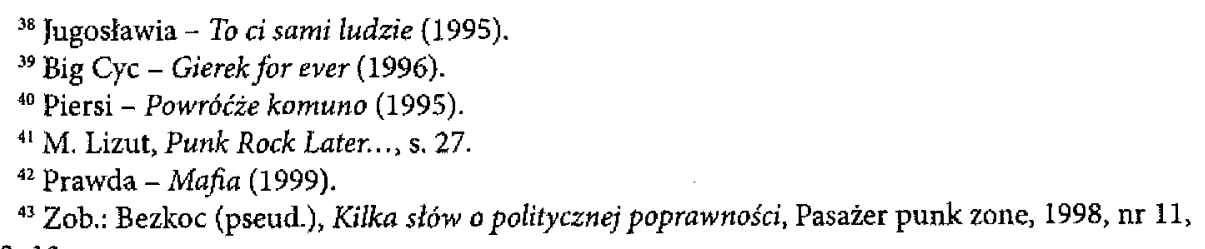
s. $12-13$.

44 Fort BS - Biurowiec (1992).

${ }^{45}$ Azotox - Nasza demokracja (1994); zob. też: Apatia - Państwo (1997). 
Ruch punk w Polsce w latach 1980-2000 stał się trwałą częścią młodzieżowego stylu życia.

W latach osiemdziesiątych muzyka punkowa spełniała swoją rolę jako wyrazicielka niechęci do systemu komunistycznego i kontestacji wszelkich narzuconych przez niego restrykcji. Członkowie tej podkultury chętnie wyrażali swoje opinie na tematy polityczne i społeczne, a ich twórczości składa się na nieszablonowy podręcznik do historii. $W$ utworach odnajdujemy komentarz do prawie wszystkich przejawów życia publicznego i politycznego. Lata 1980-1990 przesycone sa twórczością pełną bólu i nienawiści đo systemu. Czas kryzysu, w jakim przypadło żyć młodym ludziom tego okresu, był korzystny dla rozwijania się wszelkich form negacji i sprzeciwu.

Lata dziewięćdziesiąte - czas stabilizacji i normalizacji - stwarzały złudzenie wypalenia wartości punkowych oraz braku celu kontestacji. Okazało się jednak, że muzycy nadal znajdowali inspirujące ich tematy. Treść utworów punkowych tego okresu porusza đrażniące młodzież tematy w nowej rzeczywistości odradzającego się kraju. Okazało się, że panujący ustrój nie jest już tak ważny, ważne są jego patologie, tworzone przez ludzi. Bunt przeciwko nowym ograniczeniom nadal mial sens, a wytykanie palcem władzy, jej niedoskonałości było nadal ważne.

Tekst utworu punkowego jest dziś dla nas nie tylko komentarzem autora, wyrażeniem indywidualnych poglądów jednostki. Ruch punk - zwłaszcza w latach 80-tych - był zjawiskiem masowym. Muzyki tej słuchała ogromna część młodzieży, a musimy pamiętać, że świadomość słuchaczy nie była tylko i wyłącznie przez tekst piosenki punkowej kształtowana, ale i reprezentowana. Popularność muzyki punk brała się stąd, że wyrażane za jej pomocą opinie były opiniami nie tylko jej twórców, ale przede wszystkim odbiorców. Dlatego też teksty utworów punkowych nie można uznać za przydatne tylko i wylącznie w badaniach historii muzyki - są one wspaniałym źródłem naszej wiedzy z zakresu historii społecznej. 